\title{
Upaya Meningkatkan Hasil Belajar Matematika Menggunakan Metode Mind Map pada Siswa Kelas V SD Negeri 38 Ampenan
}

\author{
Nurhasanah \\ SD Negeri 38 Mataram, Kota Mataram - Provinsi NTB \\ Corresponding Author. Email: nurhasanah@gmail.com
}

\begin{abstract}
The purpose of this study was to improve student learning outcomes in mathematics learning by using the mind map method for fifth grade students of SD Negeri 38 Ampenan. The research method used is classroom action research. The research process used was the research proposed by Kemmis and Taggart which used a spiral system cycle, each cycle consisting of planning, action, observation, and reflection. The subjects in this study were 37 grade V SD Negeri 38 Ampenan students. Research data obtained from the results of observations, tests and documentation. The data analysis technique used descriptive qualitative and quantitative. The results showed that the students' mathematics learning outcomes using the Mind Map method had increased. This is indicated by an increase in the average mathematics learning outcomes of grade $\mathrm{V}$ students by $49.01 \%$. In addition, the results of the analysis of the observation data increased from $46.7 \%$ of the fulfilled aspects to $86.7 \%$ of the aspects.
\end{abstract}

\begin{abstract}
Abstrak: Tujuan penelitian ini adalah untuk meningkatkan hasil belajar siswa dalam pembelajaran matematika Bangun Ruang menggunakan metode mind map pada siswa kelas V SD Negeri 38 Ampenan. Metode penelitian yang digunakan adalah penelitian tindakan kelas. Proses Penelitian yang digunakan adalah penelitian yang dikemukakan oleh Kemmis dan Taggart yang menggunakan siklus sistem spiral yang maing-masing siklus terdiri dari rencana, tindakan, observasi, dan refleksi. Subjek dalam penelitian ini adalah siswa kelas V SD Negeri 38 Ampenan yang berjumlah 37 orang. Data hasil penelitian diperoleh dari hasil observasi, tes dan dokumentasi. Teknik analisis data menggunakan deskriptif kualitatif dan kuantitatif. Hasil penelitian menunjukkan bahwa hasil belajar matematika siswa dengan menggunakan metode Mind Map mengalami peningkatan. Hal ini ditunjukkan dengan adanya peningkatan rata-rata hasil belajar Matematika siswa kelas V sebesar 49,01\%. Selain itu dari hasil analisis data observasi mengalami peningkatan yaitu dari $46,7 \%$ aspek terpenuhi menjadi $86,7 \%$ aspek.
\end{abstract}

How to Cite Nurhasanah, N. (2021). Upaya Meningkatkan Hasil Belajar Matematika Menggunakan Metode Mind Map pada Siswa Kelas V SD Negeri 38 Ampenan. Jurnal Teknologi Pendidikan : Jurnal Penelitian dan Pengembangan Pembelajaran, 6(1). doi:https://doi.org/10.33394/jtp.v6i1.3590

d.

https://doi.org/10.33394/itp.v6i1.3590

This is an open-access article under the CC-BY-SA License.

\author{
Article History \\ Received: 24-02-2021 \\ Revised: 17-03-2021 \\ Published: 14-04-2021
}

\section{Sejarah Artikel}

Diterima: 24-02-2021

Direvisi: 17-03-2021

Diterbitkan: 14-04-2021

\author{
Kata Kunci: \\ Hasil Belajar, Mind Map.
}

\section{Pendahuluan}

Perkembangan pada era globalisasi sekarang ini menuntut adanya sumber daya manusia yang berkualitas tinggi dimana hal ini merupakan kunci untuk mencapai tujuan pembangunan. Salah satu wadah untuk mengusahakan peningkatan kualitas sumber daya manusia tersebut adalah dengan pendidikan. Sumitro, dkk (2006) menyatakan pendidikan merupakan proses pengembangan dan perilaku manusia secara keseluruhan. Selanjutnya pendidikan berguna untuk mengembangkan nilai-nilai baru dalam menghadapi tantangan ilmu, teknologi dan dunia modern.

Pembelajaran merupakan suatu kombinasi yang tersusun meliputi unsur-unsur 
manusiawi, material, fasilitas, perlengkapan dan prosedur dan yang saling mempengaruhi tujuan pembelajaran (Hamalik, 2005). Selanjutnya Ety Syarifah (2009) memaparkan Pembelajaran memiliki tiga komponen yang saling berkaitan. Ketiga komponen tersebut adalah tujuan pembelajaran, proses pembelajaran dan penilaian pembelajaran. Mata pelajaraan Matematika perlu diberikan kepada peserta didik mulai Sekolah Dasar untuk membekali peserta didik memiliki kemampuan berpikir logis, analitis, sistematis, kritis dan kreatif serta kemampuan bekerja sama (Heryekti, 2021; Lapase, 2021; Irni, 2016; Wahyuningsih, 2019).

Setiap terjadi perubahan kurikulum pembelajaran Matematika selalu ditekankan pada pembelajaran Aktif, Inovatif, Kreatif, Efektif dan Menyenangkan (PAIKEM). Akan tetapi pada prakteknya guru kesulitan menghadirkan PAIKEM tersebut dalam kelas. Proses pembelajaran saat ini terlalu mementingkan perkembangan pada tataran pengetahuan, sehingga persoalan kreativitas pada taraf pemahaman konsep, prinsip dan kemampuan menyelesaikan masalah masih perlu ditingkatkan (Suyanto dan Djihad Hisyam, 2000).

Dalam pembelajaran, pemilihan strategi dan metode pembelajaran adalah langkah yang sangat penting dan harus diperhatikan, karena akanberdampak langsung pada hasil belajar (Suarni, 2021; Yuliati, 2018). Menurut David (Sanjaya, 2006) startegi pembelajaran dapat diartikan sebagai perencanaan yang berisi tentang rangkaian kegiatan yang didesain untuk mencapai tujuan tertentu. Sedangkan metode pembelajaran merupakan langkah penting yang dapat menentukan keberhasilan pencapaian tujuan. Untuk itu dalam pemilihan metode haruslah kreatif dalam penyesuaiannya dengan tujuan pembelajaran (Sumiati dan Asra, 2007).

Dari hasil observasi proses pembelajaran Matematika kelas V SD Negeri 38 Ampenan ditemukan fakta bahwa siswa kurang memperhatikan penjelasan dari guru. Hal tersebut nampak ketika guru sedang menjelaskan masih ada beberapa siswa yang sibuk dengan teman sebangku dan tidak bisa menjawab ketika diberi pertanyaan oleh guru. Bila ditilik lebih lanjut, strategi yang diterapkan oleh guru dirasa kurang tepat sehingga materi yang akan diberikan tidak dapat tersampaikan dengan baik. Selain itu, metode pembelajaran yang digunakan oleh guru SD Negeri 38 Ampenan masih menggunakan metode ceramah. Menurut Sumiati dan Asra (2007) dalam metode ini komunikasi antar guru dan siswa pada umumnya searah. Hal ini menyebabkan kurangnya keaktifan siswa dalam pembelajaran.

Mata pelajaran Matematika umumnya dipandang sulit bagi siswa karena susah dimengerti, penuh dengan simbol dan pendekatan pembelajaran matematika yang kurang menarik. Hal ini mengakibatkan siswa cepat bosan dalam pembelajaran sehingga hasil belajar siswa tidak maksimal. Terbukti dengan rata-rata nilai matematika yang masih rendah dan sebagian besar (58\%) nilai siswa masih berada di bawah kriteria ketuntasan minimal (KKM) yaitu 62. Selain itu, rata-rata hasil belajar Matematika dalam ulangan tengah semester (UTS) dan ulangan akhir semester (UAS) siswa kelas V SD Negeri 38 Ampenan paling rendah bila dibandingkan dengan mata pelajaran lain. Terlihat dari rata-rata nilai UTS dan UAS berturut-turut adalah 65 dan 68 .

Sarana dan prasarana dapat menunjang tercapainya sebuah tujuan pembelajaran secara lebih maksimal. Kelengkapan dan keterbatasan sarana dan pra sarana dapat mempengaruhi proses dan hasil dalam pembelajaran dengan sarana yang lebih lengkap maka pembelajaran dapat disampaikan secara menarik sehingga menarik perhatian siswa. Sarana di SD Negeri 38 Ampenan dapat dikatakan sudah cukup lengkap. Akan tetapi dalam pemanfaatannya kurang maksimal. Sebagai contoh masih kurangnya guru yang menggunakan media elektronik dalam pembelajaran. 
Dalam proses pembelajaran Matematika tampak bahwa siswa belum siap menerima pelajaran yang disampaikan oleh guru. Siswa baru mampu mempelajari (baca: menghafal) fakta, konsep, prinsip, hukum, teori dan gagasan lainnya pada tingkat ingatan. Oleh karena itu, diperlukan sebuah inovasi dan kreativitas dalam pembelajaran Matematika SD kelas V agar peserta didik mampu memaksimalkan potensi yang dimiliki. Dengan potensi yang tergali secara maksimal dalam sebuah proses pembelajaran akan meningkat pula ketercapaian tujuan dan penilaian. Dari berbagai permasalahan yang ditemukan perlu adanya penerapan metode pembelajaran yang diharapkan mampu melahirkan sebuah inovasi dalam pembelajaran matematika.

Piaget (Rita Eka Izzaty, 2008) skema kognitif menunjukkan struktur mental, pola berpikir yang orang gunakan untuk mengatasi situasi tertentu di lingkungan. Misalnya, bayi melihat benda yang diinginkan kemudian menangkap benda yang dilihat tersebut sehingga membentuk skema yang tepat. Tony Buzan (2007) mengemukakan bahwa Mind Map adalah cara terbaik untuk mendapatkan ide baru dan merencanakan proyek. Mind Map adalah bentuk penulisan catatan yang penuh warna dan bersifat visual, yang bisa dikerjakan oleh satu orang atau sebuah tim terdiri atas beberapa orang. Di pusatnya terdapat sebuah gagasan atau gambaran sentral. Kemudian gagasan utama ini dieksplorasi melalui cabang-cabang yang mewakili gagasan-gagasan utama, yang kesemuanya terhubung pada gagasan sentral ini. Disetiap cabang gagasan utama ada cabang-cabang "sub-gagasan" yang mengeksplorasi tema-tema tersebut secara lebih mendalam. Dan pada cabang-sub-gagasan ini anda dapat menambahkan lebih banyak sub-cabang, sambil terus mengeksplorasi gagasan secara lebih mendalam lagi. Faktor ini membuat Mind Map memiliki ruang lingkup yang dalam dan luas, yang tidak dimiliki oleh daftar gagasan biasa. Dari pendapat yang telah dikemukakan ahli, diketahui bahwa skema kognitif dan metode Mind Map menempatkan daya visual dalam proses belajar. Dalam hal ini, maka metode Mind Map diharapkan mampu meningkatkan hasil belajar dalam pembelajaran Matematika kelas V SD Negeri 38 Ampenan. Adapun tujuan dari penelitian ini adalah untuk meningkatkan hasil belajar Matematika menggunakan metode pembelajaran Mind Map pada siswa kelas V SD Negeri 38 Ampenan.

\section{Metode Penelitian}

Metode penelitian ini adalah Penelitian Tindakan kelas (PTK). Suharsimi Arikunto (2007) menjelaskan penelitian tindakan kelas merupakan suatu pencermatan terhadap kegiatan belajar berupa sebuah tindakan, yang sengaja dimunculkan dan terjadi di dalam sebuah kelas secara bersama. Subjek penelitian ini adalah siswa kelas V SD Negeri 38 Ampenan. Sedangkan objek dari penelitian ini adalah proses penerapan metode Mind Map (peta pemikiran) pada pembelajaran matematika siswa kelas V SD Negeri 38 Ampenan.

Desain penelitian yang digunakan menunjukkan pada proses pelaksanaan penelitian yang dikemukakan oleh Kemmis dan Taggart dalam Suharsimi Arikunto (2008) yang menggunakan siklus sistem spiral, yang masing-masing siklus terdiri dari rencana, tindakan, observasi, dan refleksi. Komponen tersebut merupakan rangkaian dalam satu siklus dan jumlah siklus yang dilakukan tergantung permasalahan yang diselesaikan.

Dalam penelitian ini instrumen penelitian yang digunakan adalah observasi, tes, dan dokumentasi. Sedangkan teknik analisis data yang digunakan dala penelitian ini adalah secara kualitatif dan kuantitatif. Analisis Kuantitatif dilakukan untuk menganalisis data yang diperoleh dari hasil tes secara tertulis. Analisis data secara kualitatif dilakukan untuk menganalisis data nontes yang diperoleh dari siswa selama proses pembelajaran berlangsung. Untuk memperoleh data nontes dari responden, digunakan lembar observasi dan 
dokumentasi. Analisis data secara kualitatif ini digunakakn untuk mengetahui perubahan perilaku siswa. Selain itu data nontes juga digunakan untuk mengetahui tanggapan siswa terhadap kegiatan pembelajaran. Kriteria keberhasilan dalam penelitian ini antara lain: (1) Hasil belajar siswa dalam pembelajaran matematika minimal meningkat pada kategori "tuntas" yaitu jika nilai yang diperoleh siswa $\geq 62$ setelah diterapkan pembelajaran matematika dengan metode Mind Map. (2) Aspek pada lembar observasi pembelajaran matematika terpenuhi yang ditandai dengan kriteria hasil observasi pada rentang cukup.

\section{Hasil Penelitian dan Pembahasan Deskripsi Siklus I}

Pada siklus I ini peneliti mengawali penelitian dengan mempersiapkan ruang, dan alat yang dibutuhkan untuk menerapkan metode Mind Map. Selanjutnya peneliti membuka kelas dengan memberikan apersepsi yang berkaitan dengan partisipasi siswa dalam pembelajaran yang dilanjutkan dengan pemberian materi mengidentifikasi sifat-sifat bangun ruang sederhana menggunakan metode Mind Map. Penyampaian materi tersebut sekaligus memberikan contoh kepada siswa cara membuat catatan dengan Metode Mind Map. Selanjutnya peneliti menanyakan kepada siswa mengenai apa yang belum dipahami. Dengan demikian peneliti tahu apa saja yang masih belum dipahami. Siswa diberikan LKS setelah semua siswa benar-benar paham dengan materi yang disampaikan. Dalam LKS siswa diminta mengerjakan dengan Mind Map. Karena penginformasian kepada siswa yang belum diterima dengan baik maka masih ada beberapa siswa yang mengerjakan tidak sesuai dengan arahan. Setelah dilakukan pembahasan peneliti mengulang materi yang sudah disampaikan agar siswa benar-benar mengerti dengan materi pembelajaran. Tes siklus I diberikan setelah semua kegiatan tersebut dilalui untuk mengukur hasil belajar siswa siklus I. Untuk mengukur prestasi belajar siswa kelas V SD Negeri 38 Ampenan dilakukan dengan memberikan tes siklus 1. Ketuntasan kompetensi mengidentifikasi sifat-sifat bangun ruang setelah dilakukan tindakan kelas pada siklus I, secara visual disajikan pada grafik berikut ini:

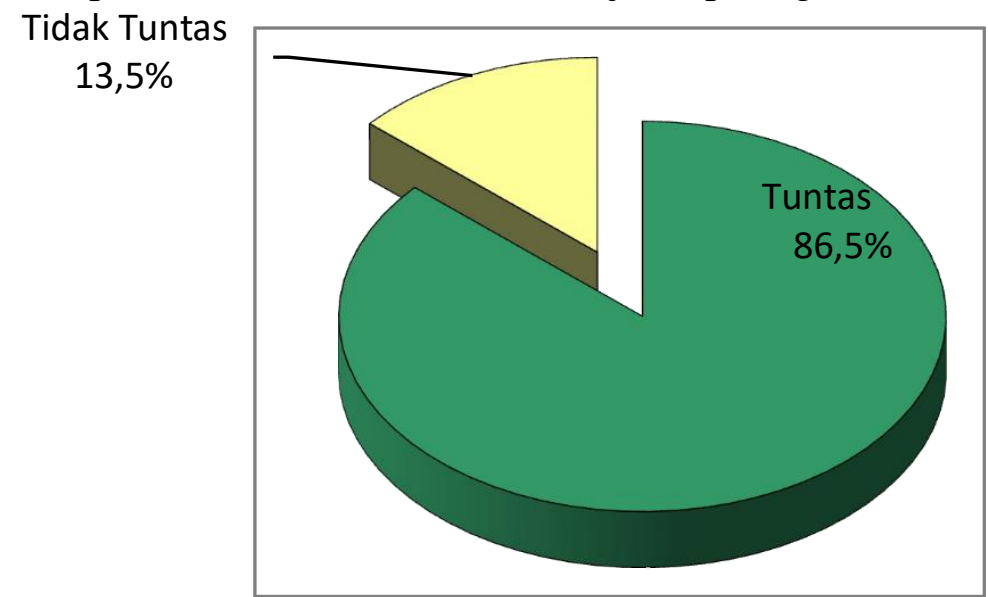

Gambar 1. Ketuntasan Kompetensi (Setelah Siklus 1)

Berdasarkan tabel dan histogram di atas setelah dilakukan tindakan kelas dengan penggunaan metode Mind Map pada siklus pertama, diketahui bahwa dari 37 siswa kelas V SD Negeri 38 Ampenan sebagai subjek penelitian, 32 (86,5\%) tuntas dalam kompetensi mengidentifikasi sifat-sifat bangun ruang dan $5(13,5 \%)$ belum tuntas dalam kompetensi mengidentifikasi sifat-sifat bangun ruang. Mengacu pada data yang diperoleh pada Siklus I tindakan kelas dengan penggunaan metode pembelajaran Mind Map menunjukan hasil yang cukup 
signifikan terjadi peningkatan kompetensi mengidentifikasi sifat-sifat bangun ruang sederhana pada siswa kelas V SD Negeri 38 Ampenan, dari kondisi awal 32,4\% siswa yang tuntas meningkat menjadi $86,5 \%$ atau terjadi penurunan siswa yang tidak tuntas, yang tadinya $67,6 \%$ siswa tidak tuntas menurun menjadi $13,5 \%$ siswa siswa. Hasil tersebut sudah mencapai target yang diharapkan, akan tetapi kenaikan tersebut dirasa belum cukup memuaskan karena masih ada siswa yang belum tuntas dengan KKM atau nilai ketuntasan minimal adalah 62. Berdasarkan observasi yang dilakukan oleh observer sebagai kolaborator peneliti, menunjukkan bahwa kegiatan pembelajaran pada siklus pertama berada pada rentang 'kurang'. Dikatakan demikan karena dari 15 item yang diamati hanya 7 item (46,7\%) saja yang sudah terpenuhi. Hasil ini tentu masih jauh dari batas keberhasilan yaitu pada rentang 'cukup'. Oleh karena itu, peneliti melakukan persiapan pada tindakan siklus kedua dengan lebih baik lagi.

\section{Deskrispsi Siklus II}

Pada siklus II ini peneliti mengawali dengan mempersiapkan ruang, dan alat yang dibutuhkan untuk menerapkan metode Mind Map. Dalam mengawali siklus II peneliti mengkondisikan siswa sebelum pembelajaran dimulai. Selanjutnya peneliti membuka kelas dengan menginformasikan metode yang akan digunakan adalah metode Mind Map dan memberikan apersepsi yang berkaitan dengan partisipasi siswa dalam pembelajaran. Dilanjutkan dengan pemelajaran materi menentukan jaring- jaring berbagai bangun ruang sederhana menggunakan metode Mind Map. Penyampaian materi tersebut sekaligus memberikan contoh kepada siswa cara membuat catatan dengan Metode Mind Map disertai dengan mengerjakan contoh-contoh soal yang diberikan guru. Dalam siklus II ini peneliti memberikan inovasi berupa penggunaan variasi warna pada catatan Mind Map yang pada siklus I belum diterapkan. Siswa juga membuat catatan Mind Map sesuai dengan ide dari siswa dalam buku masing-masing anak. Selanjutnya peneliti menanyakan kepada siswa mengenai apa yang belum dipahami. Dengan demikian peneliti tahu apa saja yang masih belum dipahami. Siswa diberikan LKS setelah semua siswa benar-benar paham dengan materi yang disampaikan. Dalam LKS siswa diminta mengerjakan dengan Mind Map yang sebelumnya telah disampaikan kepada siswa cara pengerjaannya. Selanjutnya siswa secara mengerjakan LKS yang telah diberikan dengan Mind Map. Pembahasan LKS dilaksanakan ketika semua siswa telah selesai dalam mengerjakan LKS. Dari hasil pengerjaan LKS tersebut diketahui bahwa semua siswa mampu membuat catatan Mind Map. Setelah dilakukan pembahasan LKS peneliti mengulang materi yang sudah disampaikan agar siswa benar-benar mengerti dengan materi pembelajaran. Sehingga siswa dapat mengi dentifikasi sifat-sifat bangun ruang sederhana. Contohnya, siswa mampu mengidentifikasi bahwa sifatsifat kerucut adalah alas berbentuk lingkaran dan mempunyai selimut serta titik puncak. Selanjutnya peneliti dan siswa menarik kesimpulan dari materi yang telah diberikan mengenai bangun ruang.

Tes siklus II diberikan setelah semua kegiatan tersebut dilalui untuk mengukur hasil belajar siswa siklus II. Sebelum mengakhiri pembelajaran peneliti memberikan motivasi kepada siswa untuk selalu mempertahankan konsistensi dan meningkatkan semangat belajar baik disekolah ataupun dirumah. Untuk mengukur prestasi belajar siswa kelas V SD Negeri 38 Ampenan dilakukan dengan memberikan tes siklus 2. Adapun ketuntasan kompetensi menentukan berbagai jaring- jaring bangun ruang sederhana setelah dilakukan tindakan kelas pada siklus II, secara visual disajikan pada grafik berikut ini: 


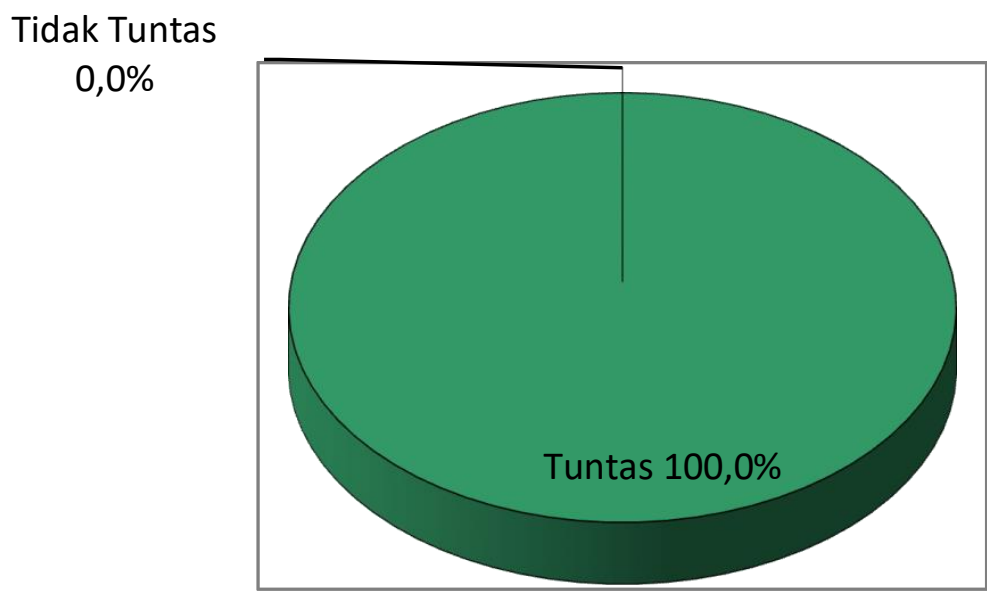

Gambar 2. Ketuntasan Kompetensi (setelah siklus 2)

Berdasarkan tabel dan histogram di atas setelah dilakukan tindakan kelas dengan penggunaan metode pembelajaran Mind Map pada siklus kedua, diketahui bahwa dari 37 siswa kelas V SD Negeri 38 Ampenan sebagai subjek penelitian, semuanya atau 100\% tuntas dalam kompetensi menentukan jaring-jaring berbagai bangun ruang sederhana. Mengacu pada analisis data pada Siklus II tindakan kelas dengan penggunaan metode Mind Map pada penelitian ini diketahui bahwa terdapat peningkatan yang signifikan kompetensi mengidentifikasi sifat- sifat bangun ruang dan menentukan jaring-jaring bangun ruang sederhana SD Negeri 38 Ampenan, dari kondisi awal 13,5\% siswa yang tuntas dan pada siklus satu $86,5 \%$ siswa yang tuntas; pada akhir siklus II ini semua (100\%) siswa tuntas dalam kompetensi menentukan jaring-jaring berbagai bangun ruang sederhana. Peningkatan tersebut secara visual disajikan dalam diagram batang berikut:

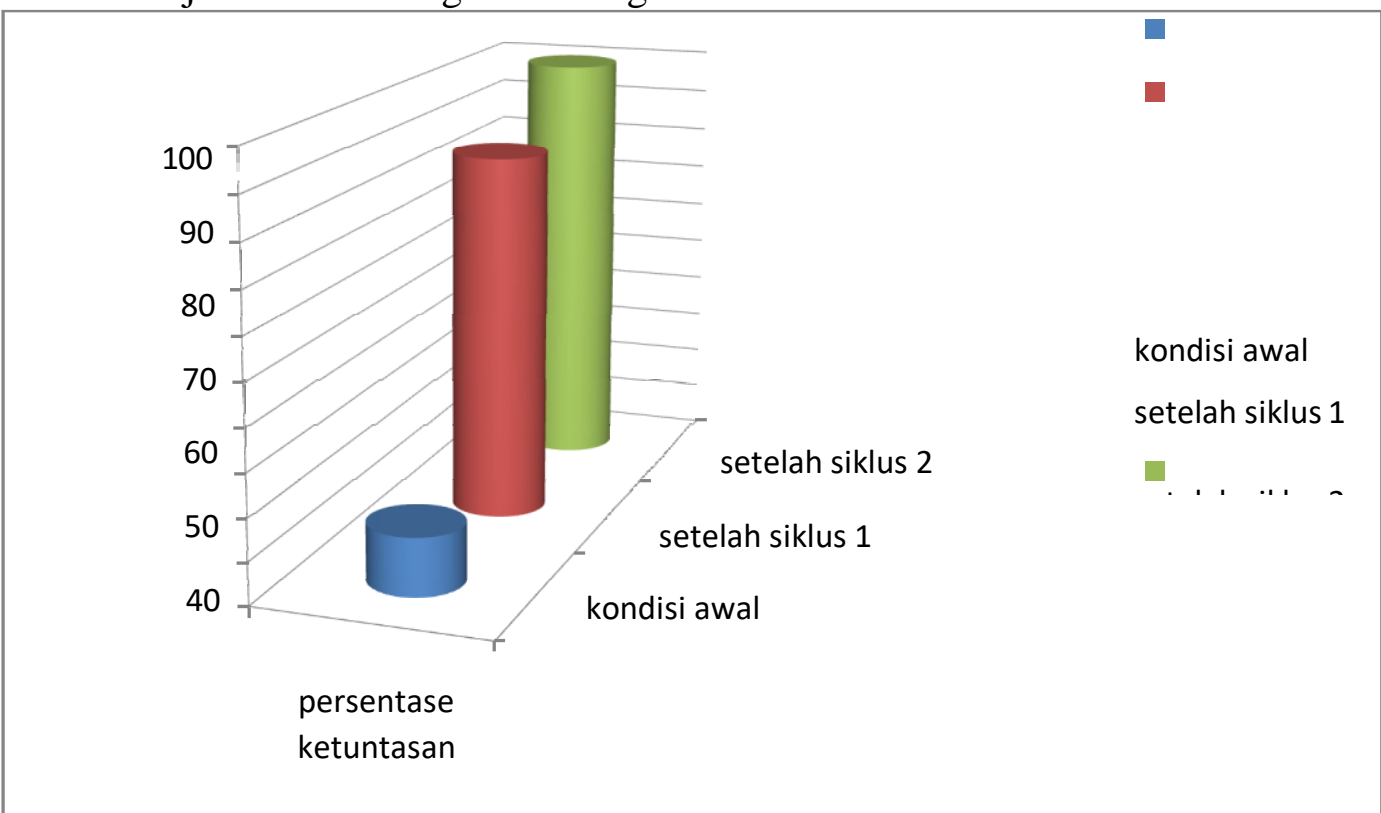

Hasil hasil tersebut sudah mencapai target yang diharapkan yakni seluruh siswa (100\%) tuntas dalam pembelajaran Matematika kompetensi menentukan jaring-jaring berbagai bangun ruang sederhana dengan Metode Mind Map. Berdasarkan observasi yang dilakukan oleh observer sebagai kolaborator peneliti, pada siklus II ini menunjukkan kegiatan pembelajaran mengalami peningkatan. Pada siklus I hasil observasi berada pada kategori 
'kurang'. Sementara hasil observasi pada siklus II ini menunjukkan dari 15 item yang diamati sejumlah 13 item sudah tercapai (86,7\%). Dengan demikian hasil observasi pada siklus II sudah memenuhi target karena berada pada kategori 'tinggi'.

\section{Pembahasan}

Hasil belajar Matematika kelas V semester 2 SD Negeri 38 Ampenan pada kondisi awal dengan rata-rata sebesar 60,27. Rata-rata ini masih dibawah dari ketuntasan (KKM) yang ditentukan, yaitu 62,00. Pada awal sebelum dilakukan tindakan kelas, sebanyak 25 $(67,6 \%)$ siswa belum tuntas dalam pembelajaran matematika pada kompetensi mengidentifikasi sifat-sifat bangun ruang sederhana dan hanya sebanyak $12(32,4 \%)$ siswa yang tuntas. Berdasarkan hasil analisis pada data akhir siklus I diperoleh rata- rata hasil belajar matematika kompetensi mengidentifikasi sifat-sifat bangun ruang sederhana sebesar 79,46. Angka ini memang sudah di atas nilai ketuntasan yang ditentukan, yaitu 62. Akan tetapi dari 37 orang siswa, masih terdapat 5 orang siswa yang belum tuntas pada kompetensi mengidentifikasi sifat-sifat bangun ruang sederhana. Pada siklus I perhatian siswa belum sepenuhnya fokus ketika pembelajaran berlangsung. Ketika diminta untuk bertanya atau mengemukakan pendapat oleh guru beberapa siswa cenderung diam karena malu. Bahkan ketika pembelajaran berlangsung ada sebagian anak yang berbuat gaduh dikelas sehingga mengganggu teman yang lain. Dilihat dari prosentase peningkatan skor, dari kondisi awal (sebelum perlakukan tindakan kelas) ke hasil siklus I, meningkat sebesar 33,16\%. Peningkatan ini cukup baik, meskipun belum seluruh siswa tuntas. Hasil analisis data pada akhir siklus II diperoleh rata-rata hasil matematika kompetensi menentukan jaring-jaring berbagai bangun ruang sederhana sebesar 87,30. Dari 37 orang siswa, semuanya (100\%) dinyatakan tuntas pada kompetensi menentukan jaring-jaring berbagai bangun ruang sederhana kelas V semester 2 SD Negeri 38 Ampenan. Dalam siklus II, terjadi peningkatan kualitas ketika pembelajaran berlangsung. Pada siklus I yang cenderung tidak fokus terhadap pembelajaran, di siklus II ini mereka menunjukkan minat yang bagus terhadap pembelajaran. Siswa lebih aktif dalam bertanya kepada guru, dan terjadi lebih sedikit kegaduhan di kelas sewaktu pembelajaran berlangsung di siklus II ini disbanding siklus I. Dilihat dari peningkatannya, rata-rata terjadi peningkatan dari pre-test (sebelum tindakan kelas) sebesar 49,01\%. Peningkatan ini cukup signifikan, karena dari 67,6\% siswa yang belum tuntas menjadi $100 \%$ siswa tuntas pada kompetensi menentukan jaring-jaring berbagai bangun ruang sederhana.

Selain itu, data observasi pun mengalami peningkatan yang cukup signifikan. Pada siklus 1 hasil observasi menunjukkan data 46,7\% yakni berada pada kategori 'sedang'. Sementara hasil olah data observasi siklus 2 menunjukkan angka 86,7\% yakni berada pada kategori 'tinggi'. Dari hasil-hasil tersebut di atas, terbukti bahwa metode Mind Map mampu meningkatkan prestasi belajar pada mata pelajaran Matematika kelas V semester 2 SD Negeri 38 Ampenan.

\section{Kesimpulan}

Kesimpulan yang diperoleh dari hasil penelitian ini adalah Metode Mind Map dapat meningkatkan hasil belajar matematika siswa kelas V SD Negeri 38 Ampenan pada tiap siklusnya. Rata-rata peningkatan hasil belajar matematika siswa kelas V SD Negeri 38 Ampenan sebesar 49,01\% dari prasiklus sampai akhir siklus 2. Pada siklus I persentase yang dicapai dari keseluruhan aspek yang diamati menghasilkan data 46,7\% aspek terpenuhi. Setelah dilanjutkan pada siklus II persentase pemenuhan aspek menjadi $86,7 \%$ atau berada 
pada kategori tinggi.

\section{Saran}

Mengacu pada hasil penelitian dan simpulan di atas, beberapa saran yang dapat disampaikan antara lain:

(1) Diharapkan kepada guru kelas supaya menggunakan metode Mind Map agar dapat memudahkan siswa dalam memahami materi pelajaran, terutama pembelajaran matematika dengan materi pokok bangun ruang.

(2) Pembelajaran menggunakan Mind Map membutuhkan kreativitas yang tinggi. Oleh karena itu guru harus berlatih secara berkesinambungan dalam penggunaan metode Mind Map terutama dalam pembelajaran Matematika.

(3) Perlu dilakukannya penelitian lain dengan menggunakan metode-metode yang lain untuk dapat diabndingkan agar diperoleh media yang efektif dalam meningkatkan hasil belajar matematika materi memahami sifat-sifat bangun dan hubungan antar bangun.

\section{Daftar Pustaka}

Asep Jihad. (2008). Pengembangan Kurikulum Matematika. Jakarta: Multi Pressindo.

Buzan. Tony dan Barry. (2004) . Mind Map: untuk Meningkatkan Kreativitas. Jakarta Gramedia: Pustaka Utama.

Erman Suherman, dkk. (2003). Strategi Pembelajaran Matematika Kontemporer. Bandung: JICA UPI.

Erman Suherman,dkk. (2001). Strategi Pembelajaran Matematika Kontemporer. Bandung: JICA UPI.

Herman Hudojo. (2005). Pengembangan Kurikulum dan Pembelajaran Matematika. Cetakan I. Malang: Universitas Negeri Malang (UM Pres).

Heryekti Pujingsih, R. (2021). Meningkatkan Motivasi dan Hasil Belajar Matematika dengan Metode Kooperatif Tipe Jigsaw di SMA Negeri 1 Gerung. Jurnal Paedagogy, 8(1), 50-56. doi:https://doi.org/10.33394/jp.v8i1.3196

Lapase, M. (2021). Implementasi Pembelajaran Berbasis Proyek untuk Meningkatkan Hasil Belajar Siswa pada Mata Pelajaran Matematika di SD Negeri Pinedapa. Jurnal Paedagogy, 8(2), 134-143. doi:https://doi.org/10.33394/jp.v8i2.3492

Muhibbinsyah. (2005). Psikologi Pendidikan dengan Pendekatan Baru. Bandung: Remaja Rosdakarya.

Irni, H. (2016). Pemanfaatan Bahan Sederhana Menjadi Alat Peraga Keranjang Faktor untuk Meningkatkan Hasil Belajar Matematika Materi FPB dan KPK pada Siswa Kelas V SDN 10 Mataram. Jurnal Kependidikan: Jurnal Hasil Penelitian dan Kajian Kepustakaan di Bidang Pendidikan, Pengajaran dan Pembelajaran, 2(2). doi:https://doi.org/10.33394/jk.v2i2.453

Oemar Hamalik. (2005). Kurikulum dan Pembelaqjaran. Jakarta: Bumi Aksara. Purwanto. (2011). Evaluasi Hasil Belajar. Jakarta: Pustaka Pelajar.

Rita Eka Izzaty,dkk. (2008). Perkembangan Peserta Didik. Yogyakarta: Uny Press.

Sanjaya, Wina. (2006). Strategi pembelajaran berorientasi standar proses pendidikan. Jakarta: Kencana Prenada Media Group.

Suarni, G., Rizka, M., \& Zinnurain, Z. (2021). Analisis Pengaruh Penerapan Model Pembelajaran Sains Teknologi Masyarakat Terhadap Hasil Belajar Siswa. Jurnal Paedagogy, 8(1), 31-38. doi:https://doi.org/10.33394/jp.v8i1.3226 
Suharsimi Arikunto,dkk. (2007). Penelitian Tindakan Kelas. Jakarta: Bumi Aksara.

Suharsimi Arikunto. (2007). Penelitian Tindakan Kelas. Jakarta: Bumi Aksara.

Sumitro, Dwi S,dkk. (2006). Pengantar Ilmu Pendidikan. Yogyakarta: Fakultas Ilmu Pendidikan Universitas Negeri Yogyakarta.

Sumiyati, Asra. (2007). Metode Pembelajaran. Bandung: CV Wacana Prima.

Suyanto, Djihad Hasyim. (2000). Pendidikan Indonesia menanti Milenium III. Yogyakarta: Adi Cipta Karya.

Syaiful Bahri Djamarah. (2002). Psikologi Belajar. Jakarta: Rineka Cipta.

Syamsu Yusuf Ln. (2006). Psikologi Perkembangan Anak dan Remaja. Bandung: PT Remaja Rosdakarya.

Syarifah Ety. (2009). Analisis dan Interpretasi Data dalam Penelitian Tindakan Kelas. Semarang: Bandungan Institute.

Wahyuningsih, W. (2019). Penerapan Metode Latihan Mandiri Untuk Meningkatkan Hasil Belajar Matematika pada Siswa SMP Negeri 1 Kayangan. Jurnal Kependidikan: Jurnal Hasil Penelitian dan Kajian Kepustakaan di Bidang Pendidikan, Pengajaran dan Pembelajaran, 5(2), 149-155. doi:https://doi.org/10.33394/jk.v5i2.1813

Yuliati, G. (2018). Peningkatan Hasil Belajar Matematika Siswa Kelas XI IPA 3 SMA Negeri 1 Batukliang Melalui Penggunaan Model Pembelajaran Student Teams Achievement Division. Jurnal Kependidikan: Jurnal Hasil Penelitian dan Kajian Kepustakaan di Bidang Pendidikan, Pengajaran dan Pembelajaran, 4(1), 31-40. doi:https://doi.org/10.33394/jk.v4i1.899 